\title{
Association between socioeconomic status and cardiovascular risk
}

\author{
Krystyna Kozakiewicz ${ }^{1}$, Ewa Podolecka ${ }^{1}$, Magdalena Kwaśniewska², Wojciech Drygas ${ }^{3}$, \\ Andrzej Pająk $k^{4}$ Michał Tendera ${ }^{1}$ \\ $13^{\text {rd }}$ Department of Cardiology, Upper Silesian Centre of Cardiology, Medical University of Silesia, Katowice, Poland \\ ${ }^{2}$ Department of Preventive Medicine, Medical University, Lodz, Poland \\ ${ }^{3}$ Department of Epidemiology, Cardiovascular Prevention and Health Promotion, Institute of Cardiology, Warsaw, Poland \\ ${ }^{4}$ Department of Epidemiology and Population Studies, Institute of Public Health, Jagiellonian University Medical College, Krakow, Poland
}

\section{A bstract}

Background: Cardiovascular disease (CVD) is one of the major health problems of the modern societies. Socioeconomic status (SES) is an important predictor of CVD and its risk factors.

Aim: To examine whether SES is related to an increased cardiovascular (CV) risk in the population of southwestern Poland. Methods: The study population comprised 2027 subjects, including 929 (45.8\%) men and 1098 (54.2\%) women participating in the WOBASZ study. From this population, we selected a subgroup of 1821 subjects free from CVD, including 816 men and 1005 women, all with defined SES. Their CV risk was estimated using the SCORE risk algorithm and an analysis of the relationship between SES indicators and the SCORE risk was performed.

Results: We found a negative correlation between the SCORE risk and SES ( $p=0.0005)$. In the overall study group and among participating women, the SCORE risk was significantly lower among subjects with high SES (SES score $>12$ ). This relation was also noted in men and women aged 30-39 years $(p=0.02)$, women aged $30-39$ years $(p=0.0001)$ and $40-49$ years $(p=0.04)$, and in men aged 70-74 years $(p=0.046)$. With an increase in SES, the proportion of high CVD risk subjects decreased significantly in the overall study population and in those aged $30-39$ years $(p=0.01)$. Similar relations were observed in women in the entire age range and those aged $30-39$ years $(p=0.01)$. We found that SES had a significant effect on the rate of high CVD risk in all study subgroups aged $30-39$ years (odds ratio $0.57,95 \% \mathrm{Cl} 0.39-0.85, \mathrm{p}=0.005$ in men and women overall; odds ratio: $0.6,95 \% \mathrm{Cl} 0.37-0.99, \mathrm{p}=0.045$ in men; and odds ratio: $0.4,95 \% \mathrm{Cl} 0.16-0.99, \mathrm{p}=0.01$ in women) Conclusions: Socioeconomic status was found to be a predictor of high CVD mortality risk in men and women aged 30-39 years. Key words: socioeconomic status, cardiovascular risk

Kardiol Pol 2016; 74, 2: 179-184

\section{INTRODUCTION}

Cardiovascular disease (CVD) is a serious health problem of the modern societies and a major cause of mortality, responsible for more than 17 million deaths annually worldwide. It has been estimated that by 2020, this number will have increased to 25 million, or $37 \%$ of the total mortality [1]. CVD is responsible for premature mortality, morbidity, and disability in the working-age population. Of particular importance, coronary artery disease (CAD) is responsible for nearly half of all deaths due to cardiovascular (CV) causes [1]. The observed increase in $\mathrm{CV}$ mortality has been called the epidemiologic transition and is associated with economic, social, and demographic changes in various populations [2,3]. Disease incidence and mortality rates are affected by many factors, such as social, environmental, and economic factors. The socioeconomic status (SES) is a significant predictor of CVD and its risk factors [4-6].

In epidemiological studies, SES is evaluated based on education, income, and profession or employment. Each of these parameters has some limitations and thus they have all been used at varying rates to evaluate SES in research studies.

Data on mortality trends, summarised by Kaplan and Keil [7], indicate a strong association between education 
and the mortality risk. This relationship was also observed in other studies [5, 8]. In the study by Mackenbach et al. [5] who evaluated CV mortality rates and the prevalence of CV risk factors among men and women aged 30-59 years in 11 European countries, higher CV mortality was found in less educated subjects with a lower professional status compared to those better educated and with a higher professional status.

Income is less frequently used to evaluate SES in epidemiological studies. In studies that evaluated the relation between SES and population health, total family income was negatively correlated with the mortality risk [9].

In most countries, clear differences in CVD incidence and mortality are seen in relation to SES $[6,10]$. Studies indicate that low SES is associated with higher CVD morbidity and mortality CVD $[5,11]$. In addition, an abnormal health behaviour pattern, with an increased incidence of premature CAD, is seen in low SES groups [11].

The aim of the study was to evaluate the relation between SES and an increased CV risk in the population of southwestern Poland.

\section{METHODS}

This study is a part of the Wieloośrodkowe Ogólnopolskie Badanie Stanu Zdrowia Ludności (WOBASZ) study [12], undertaken within the National Program for Cardiovascular Disease Prevention and Treatment (Narodowy Program Profilaktyki i Leczenia Chorób Układu Sercowo-Naczyniowego, POLKARD 2003-2005) of the Polish Ministry of Health.

The study group included randomly selected inhabitants of the Silesian (śląskie), Opole (opolskie), and Lower Silesian (dolnośląskie) provinces (voivodships). Random sample selection was performed in the Section of State Registries (Departament Rejestrów Państwowych), Ministry of the Interior and Administration (MSWiA) among Polish citizens with available permanent residence address and no recorded objection to personal data processing. Following commune stratification based on the number of inhabitants aged 20-74 years, 3 commune categories were identified: small communes with less than 8000 inhabitants, middle-sized communes with 8000-40000 inhabitants, and large communes with more than 40000 inhabitants. In each province, 6 communes were randomly selected ( 2 small, 2 middle-sized, and 2 large), using a list provided by the Central Statistical Office (Główny Urząd Statystyczny), and then 100 men and 100 women aged 19-75 years were randomly selected in each commune. Of 3600 randomly selected inhabitants of the Silesian, Opole, and Lower Silesian provinces, 2287 subjects (1064 men and 1223 women) took part in the study but subjects with missing data on the evaluated variables (education and income) were excluded from the analysis.

Ultimately, the study group included 2027 subjects including 929 men (median age 46 years, range 20-74 years) and 1098 women (median age 46 years, range 20-74 years).
A subgroup of 1821 subjects (816 men and 1005 women) free from CVD was identified in the study group and had their CV risk estimated using the Systematic Coronary Risk Evaluation (SCORE) risk algorithm. A relation between SES parameters and the SCORE risk was evaluated.

Subjects invited to participate in the study were informed about the nature and purpose of the study and gave their written consent to participate. The study was approved by the Bioethics Committee at the National Institute of Cardiology in Warsaw.

History taking and physical examination included a questionnaire, blood pressure measurements, anthropometric data measurements (height, weight, waist and hip circumference). The questionnaire included demographic data, social variables (age, gender, education, family income per person), and addictions including tobacco smoking. Laboratory tests included fasting serum lipid profile and glucose level.

The evaluated socioeconomic variables were education and net family income per person.

Due to lacking standardised SES definition recommended by scientific societies, socioeconomic groups were defined using the approach used in the ATTICA study [13]. SES was defined as a product of education and income, with ordinal numerical values assigned to various categories of these two variables (education: incomplete primary school or no education $=1$, primary school $=2$, high school vocational $=3$, incomplete high school $=4$, high school $=5$, vocational higher than high school $=6$, incomplete university level $=7$, university level = 8; income in PLN: $\leq 300=1,301-500=2$, $501-700=3,701-1000=4,1001-1500=5,>1500$ PLN =6). The SES index calculated this was ranged from 1 to 48 . For further analysis, three ranges of the SES index values close to tertiles were defined, with cut-off values defined in the overall study population. This definition is based on the approach used in the ATTICA study which was modified and adjusted to the questions in the WOBASZ study questionnaire.

The following SES groups were defined: low SES $<6$, moderate SES 6-12, and high SES $>12$. Cardiovascular risk was estimated in the socioeconomic groups defined as above, using the SCORE risk algorithm for higher-risk European countries [14].

\section{SCORE risk}

Cardiovascular risk in the studied subpopulation was estimated using the SCORE risk algorithm developed under the European Concerted Action Project [14]. This risk estimate is based on age, gender, systolic blood pressure, total cholesterol level, and smoking. The SCORE risk algorithm is used to stratify risk in primary prevention in subjects without established CVD [14]. Its purpose is to estimate the overall risk of CVD (myocardial infarction, ischaemic stroke, peripheral arterial disease). In this model, the risk is defined as the 10-year likelihood of a fatal CV event. 
Table 1. Relation between socioeconomic status and the SCORE risk in various gender and age groups

\begin{tabular}{|c|c|c|c|c|c|c|}
\hline \multirow[t]{2}{*}{ Age } & \multicolumn{2}{|c|}{ Overall } & \multicolumn{2}{|c|}{ Men } & \multicolumn{2}{|c|}{ Women } \\
\hline & R Spearman & $\mathbf{P}$ & R Spearman & $\mathbf{P}$ & R Spearman & $\mathbf{P}$ \\
\hline Overall range & -0.11 & 0.000006 & -0.09 & 0.008 & -0.17 & $<0.000001$ \\
\hline 20-29 years & 0.0 & 1.0 & -0.1 & 0.18 & -0.01 & 0.88 \\
\hline 30-39 years & -0.16 & 0.003 & -0.11 & 0.17 & -0.29 & 0.00004 \\
\hline $40-49$ years & -0.08 & 0.1 & -0.03 & 0.65 & -0.15 & 0.03 \\
\hline 50-59 years & -0.05 & 0.3 & -0.03 & 0.72 & -0.06 & 0.37 \\
\hline $60-69$ years & -0.07 & 0.31 & -0.19 & 0.07 & -0.03 & 0.73 \\
\hline 70-74 years & -0.07 & 0.72 & -0.31 & 0.1 & 0.0 & 1.00 \\
\hline
\end{tabular}

High risk group included subjects without clinical CVD symptoms with the SCORE risk $\geq 5 \%$, subjects with largely elevated total cholesterol level $\geq 320 \mathrm{mg} / \mathrm{dL}(8 \mathrm{mmol} / \mathrm{L})$ or low density cholesterol level $\geq 240 \mathrm{mg} / \mathrm{dL}$ (6 mmol/L), blood pressure $\geq 180 / 110 \mathrm{~mm} \mathrm{Hg}$, those with clinical symptoms of CVD (CAD, history of stroke, peripheral arterial disease), and subjects with diabetes [14].

\section{Statistical analysis}

Due to non-normal distribution of the evaluated quantitative variables, they were reported as median values (ranges), and statistical hypotheses were verified with nonparametric tests. Categorical variables were reported as the rates of specific categories in percentages.

Relations between the SCORE risk and SES index values treated as continuous variables were evaluated using the Spearman rank correlation. Analyses were stratified for age and gender. Similarly, we also evaluated differences in the rates of the SCORE risk $\geq 5 \%$ in relation to the SES group.

The predictive value of SES groups in various age and gender groups was determined using logistic regression. When performing analyses that included the entire age range, age was included in the model (fitting). Results were reported as odds ratios (95\% confidence interval $[\mathrm{Cl}])$. Relations and differences with $p<0.05$ were considered significant.

\section{RESULTS}

The study group included 1821 subjects (816 men and 1005 women). Their CV risk was estimated using the SCORE risk algorithm and the relation between SES and the SCORE risk was evaluated (Table 1). We found significant negative correlations between SES and the SCORE risk in men and women in the entire age range $(r=-0.11, p=0.000006)$ and those aged $30-39$ years $(r=-0.16, p=0.003)$, men in the entire age range $(r=-0.09, p=0.008)$, and in women in the entire age range $(r=-0.17, p<0.000001)$ and those aged 30-39 years $(r=-0.29, p=0.00004)$.

Analysis of the rates of high CVD risk in SES groups showed a negative relation between the proportion of high risk subjects and SES (Table 2). With an increase in SES, the proportion of high CVD risk subjects decreased significantly in the overall study population and in those aged 30-39 years $(p=0.01$ ) (Table 2). Similar relations were observed in women in the entire age range and those aged $30-39$ years $(p=0.01)$ (Table 2). SES had a significant effect on the rate of high CVD risk in all study subgroups aged 30-39 years (odds ratio: 0.57 , 95\% $\mathrm{Cl} 0.39-0.85, \mathrm{p}=0.005$ in men and women overall; odds ratio: $0.6,95 \% \mathrm{Cl} 0.37-0.99, \mathrm{p}=0.045$ in men; and odds ratio: $0.4,95 \% \mathrm{Cl} 0.16-0.99, \mathrm{p}=0.01$ in women) (Table 3).

\section{DISCUSSION}

Measurements of SES are difficult and SES indicators that would provide the most objective evaluation of the social status and have the effect on population health are still under investigation. Various approaches to measure SES have been used in epidemiological studies but the most commonly used indicators include education, income, wealth, and professional status. The present study is the first to characterise the population of southwestern Poland in relation to education and income, define socioeconomic groups based on these variables and show differences in the rates of risk factors and the overall level of $\mathrm{CV}$ risk in relation to the social status.

In the present study, we attempted to determine associations between socioeconomic factors and the CV risk. The risk of CVD is significantly affected by the lifestyle. Many authors investigating the relation between socioeconomic factors and CVD agree that adverse health-related behaviours are more commonly seen in lower SES groups $[6,7,15,16]$. This association was confirmed, among others, by Mackenbach et al. [6] in an analysis of data from 11 developed countries in which CVD mortality rates were higher in subjects aged 30-59 years from a low social status group, defined based on the education level and profession. Also in the CHEWE study, investigating the causes of high CVD mortality and incidence, particularly due to CAD, a higher coronary risk was found among low educated subjects in the Central and Eastern European countries [17].

Men and women in low social status groups are more frequently obese, eat a high-fat diet, and smoke cigarettes. A par- 
Table 2. Prevalence of a high cardiovascular disease risk in socioeconomic status categories in relation to gender and age

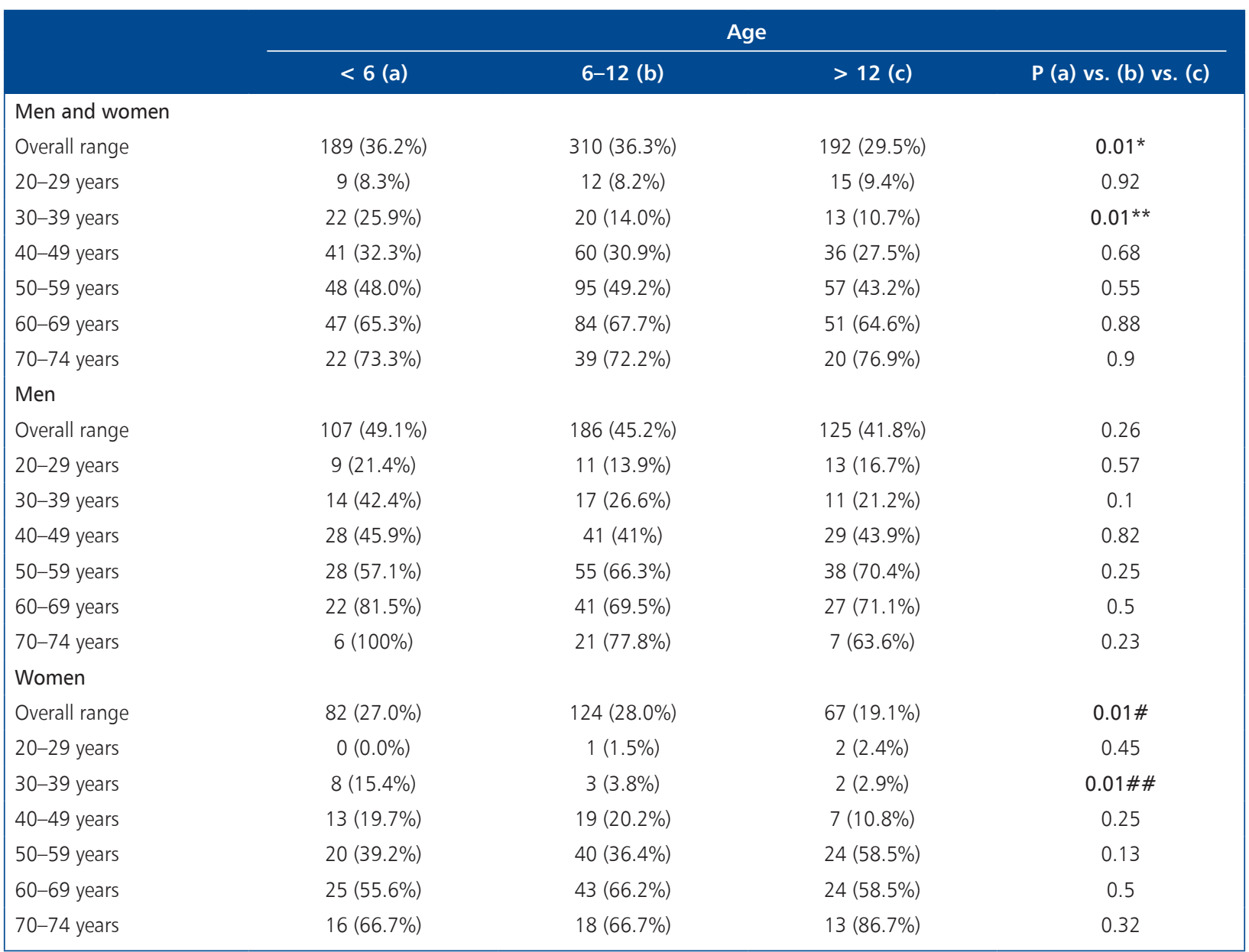

${ }^{*}$ (a) vs. (b): $p=N S$; (a) vs. (c): $p=0.02 ;$ (b) vs. (c): $p=0.006 ;{ }^{* *}(a)$ vs. (b): $p=0.03 ;$ (a) vs. (c): $p=0.004 ;$ (b) vs. (c): $p=N S$ $\#$ (a) vs. (b): $p=N S$; (a) vs. (c): $p=0.02$; (b) vs. (c): $p=0.004$; \#\#(a) vs. (b): $p=0.02$; (a) vs. (c): $p=0.01$; (b) vs. (c): $p=N S$

ticular role is believed to be played by cigarette smoking which accounts for $28 \%$ of the differences in CHD incidence between various social groups [15]. Healthy lifestyle among subjects with a higher social status may be partially explained by higher health awareness in this group [18]. Multiple studies showed that differences in the CV risk between various socioeconomic groups are partially associated with different rates of risk factors such as hypertension, hypercholesterolaemia, and particularly cigarette smoking and excess alcohol intake $[6,15]$. Literature data indicate that CVD risk level is significantly affected not only by the conventional but also psychosocial risk factors. These include, among others, marital status, work duties, chronic work stress, effort-reward imbalance, and health status self-evaluation. The above listed psychosocial factors were not a subject of analysis in the present study but they likely affected CV risk in the study population and might have contributed to the different result obtained in young women and men in their thirties compared to the findings in the overall study population [18].
In the age-stratified analysis, SES was an independent predictor of high $\mathrm{CV}$ risk but only in young men and women aged 30-39 years. In Western societies, indicators of SES strongly correlate with each other, as higher education is associated with a work post that provides professional and financial satisfaction. All these indicators correlate negatively with CVD and its risk factors. For these reasons, it is difficult to separate their effect and identify the most important indicator of CVD risk. This situation is different in former communist countries of Central and Eastern Europe, including Poland. In these countries, higher education was not rewarded with higher income. Both male and female study participants aged 30-39 years received their education and achieved their professional status in the transition period of political and economic changes that have been occurring in our country for the last 17 years. Among these participants, the correlation between education and income may be similar to that in highly developed countries. Of note, psychosocial factors that accelerate the development of CVD, such as chronic work 
Table 3. Odds ratio of a high cardiovascular disease risk in relation to socioeconomic status, stratified for gender and age (only significant values are given)

\begin{tabular}{|c|c|c|}
\hline Age & Odds ratio $(95 \% \mathrm{Cl})$ & $\mathbf{P}$ \\
\hline \multicolumn{3}{|c|}{ Men and women } \\
\hline 20-29 years & - & 0.74 \\
\hline 30-39 years & $0.57(0.39-0.85)$ & 0.005 \\
\hline 40-49 years & - & 0.4 \\
\hline 50-59 years & - & 0.42 \\
\hline 60-69 years & - & 0.91 \\
\hline 70-74 years & - & 0.77 \\
\hline Overall* & - & 0.07 \\
\hline \multicolumn{3}{|l|}{ Men } \\
\hline 20-29 years & - & 0.62 \\
\hline 30-39 years & $0.6(0.37-0.99)$ & 0.045 \\
\hline 40-49 years & - & 0.84 \\
\hline $50-59$ years & - & 0.17 \\
\hline 60-69 years & - & 0.41 \\
\hline 70-74 years & - & 0.11 \\
\hline Overall* & - & 0.22 \\
\hline \multicolumn{3}{|l|}{ Women } \\
\hline 20-29 years & - & 0.26 \\
\hline 30-39 years & $0.4(0.16-0.99)$ & 0.01 \\
\hline $40-49$ years & - & 0.18 \\
\hline $50-59$ years & - & 0.06 \\
\hline 60-69 years & - & 0.75 \\
\hline 70-74 years & - & 0.22 \\
\hline Overall* & - & 0.07 \\
\hline
\end{tabular}

*With the effect of age included in the analysis; $\mathrm{Cl}$ — confidence interval

stress, symptoms of depression, and lack of social support, are less commonly present in those with a high social status.

\section{Limitations of the study}

Data on income and education were based on participants' answers to questionnaire items. Although the questionnaire was anonymous, it cannot be excluded that some participants rated their income too high or too low, which might have an effect on the categorisation of these subjects into various SES groups. In the study, we did not account for other psychosocial factors that affect $\mathrm{CV}$ risk such as chronic work stress and effort-reward imbalance.

\section{CONCLUSIONS}

In the present study, our analysis of the relations between SES and the SCORE risk showed that lower SES was associated with an increased CVD risk in the studied population. In addition, the association between the SCORE risk and low SES was stronger in women compared to men, with a significant relation seen in women in the entire age range and in those aged 30-39 years, and in men only in the entire age range.

Conflict of interest: Andrzej Pają - a grant from the Wellcome Trust and the National Institute of Aging Grant for research on psychosocial risk factors, lecture fee from AMGEN POLSKA Sp. z o.o.

\section{References}

1. World Health Organization report. Risks to Health 2002. WHO, Geneva 2002.

2. Wojtyniak B, Goryński P, Seroka W. Highlights on the health status of the Polish population in 1999/2000. Przegl Epidemiol, 2002; 56: 179-192.

3. Yusuf S, Reddy S, Ounpuu S, Anand S. Global burden of cardiovascular diseases, part I: general considerations, the epidemiologic transition, risk factors and impact of urbanization. Circulation, 2001; 104: 2746-2753.

4. Cappuccio FP. Commentary: Epidemiological transition, migration, and cadiovascular disease. Intern J Epidemiol, 2004; 33: 387-388.

5. Mackenbach JP, Kunst AE, Groenhof F et al. Socioeconomic inequalities in mortality among women and among men: an international study. Am J Public Health, 1999; 89: 1800-1806.

6. Mackenbach JP, Cavelaars AE, Kunst AE et al. Socioeconomic inequalities in cardiovascular disease mortality. An international study. Eur Heart J, 2000; 21: 1141-1151.

7. Kaplan GA, Keil JE. Socioeconomic factors and cardiovascular disease: A review of the literature. Circulation, 1993; 88: 1973-1998.

8. Feldman JJ, Makuc DM, Kleinman JC, Cornoni-Huntley J. National trends in educational differentials in mortality. Am J Epidemiol, 1989; 129: 919-933.

9. Doornbos G, Kromhout D. Educational level and mortality in a 32-year follow-up study of 18-year-old men in The Netherlands. Int J Epidemiol, 1990; 19: 374-379.

10. Nilsson PM, Nilsson JA, Berglund G. Family burden of cardiovascular mortality: risk implications for offspring in a national register linkage study based upon the Malmoe Preventive Project. J Intern Med, 2004; 255: 229-235.

11. Avendano M, Kunst $\mathrm{AE}$, van Lenthe $\mathrm{F}$ et al. Trends in Socioeconomic Disparities in Stroke Mortality in Six European Countries between 1981-1985 and 1991-1995. Am J Epidemiol, 2005; 161: 52-61.

12. Rywik S, Broda G, Piotrowski W, Drygas W. Wieloośrodkowe ogólnopolskie badanie stanu zdrowia ludności-program WOBASZ. Pol Przegl Kardiol, 2004; 6: 77-83.

13. Panagiotakos DB, Pitsavos CE, Chrysohoou CA et al. The association between eduacational status and risk factors related to cardiovascular disease in healthy individuals: the ATTICA study. Ann Epidemiol, 2004; 14: 188-194.

14. Conroy RM, Pyorala K, Fitzgerald AP et al. Estimation of ten-year risk of fatal cardiovascular disease in Europe: the SCORE project. Eur Heart J, 2003; 24: 987-1003.

15. Emberson JR, Whincup PH, Morris RW, Walker M. Social class differences in coronary heart disease in middle-aged British men: implications for prevention. Intern J Epidemiol, 2004; 33: 289-296.

16. Martikainen P, Valkonen T Martelin T. Change in male and female life expectancy by social class: decomposition by age and cause of death in Finland 1971-1995. J Epidemiol Community Health, 2001; 55: 494-499.

17. Bobak M, Marks D, Bosma H, Pająk A, Stafford M. Explaining socioeconomoc variations in coronary heart disease across Eastern and Western Europe (The CHEWE Network). Final Report to the European Commission, 1996.

18. Prus SG, Gee E. Gender differences in the influence of economic, lifestyle, and psychosocial factors of later-life health. Can J Public Health, 2003; 94: 306-309.

Cite this article as: Kozakiewicz K, Podolecka E, Kwaśniewska M et al. Association between socioeconomic status and cardiovascular risk. Kardiol Pol, 2016; 74: 179-184. doi: 10.5603/KP.a2015.0139. 


\title{
Związek między pozycją socjoekonomiczną a ryzykiem schorzeń układu sercowo-naczyniowego
}

\author{
Krystyna Kozakiewicz ${ }^{1}$, Ewa Podolecka ${ }^{1}$, Magdalena Kwaśniewska², Wojciech Drygas ${ }^{3}$, \\ Andrzej Pająk ${ }^{4}$, Michał Tendera ${ }^{1}$ \\ 1'II Oddział Kardiologii, Górnośląski Ośrodek Kardiologii, Śląski Uniwersytet Medyczny, Katowice \\ ZZakład Medycyny Zapobiegawczej, Uniwersytet Medyczny, Łódź \\ ${ }^{3}$ Zakład Epidemiologii, Prewencji Chorób Układu Krążenia i Promocji Zdrowia, Instytut Kardiologii, Warszawa \\ ${ }^{4}$ Zakład Epidemiologii i Badań Populacyjnych, Instytut Zdrowia Publicznego, Uniwersytet Jagielloński, Collegium Medicum, Kraków
}

\section{Streszczenie}

Wstęp: Choroby układu sercowo-naczyniowego (CVD) są jednym z głównych problemów zdrowotnych współczesnych społeczeństw. Na występowanie chorób i na współczynnik zgonów wpływają m.in. czynniki społeczne, środowiskowe i ekonomiczne. Jednym z istotnych czynników prognostycznych wystąpienia CVD i ich czynników ryzyka jest pozycja socjoekonomiczna (SES).

Cel: Celem pracy było zbadanie, czy istnieje związek między SES a podwyższonym ryzykiem CVD w populacji zamieszkałej w południowo-zachodnim regionie Polski.

Metody: Analizowana grupa liczyła 2027 osób, 929 (45,8\%) mężczyzn i 1098 (54,2\% kobiet) biorących udział w badaniu WOBASZ. Z badanej grupy wyodrębniono subpopulację, tj. osoby, u których nie stwierdzono CVD. Grupa ta liczyła 1821 osób, w tym 816 męż̇zyzn i 1005 kobiet. Określono u nich ryzyko sercowo-naczyniowe na podstawie algorytmu SCORE i przeprowadzono analizę zależności między wskaźnikami SES i SCORE.

Wyniki: Analiza wartości SCORE w grupach socjoekonomicznych wykazała ujemną korelację między wartością SCORE a pozycją społeczną ( $p=0,0005)$. W całej grupie oraz w podgrupie kobiet wskaźnik SCORE był znamiennie niższy wśród osób należących do grupy o wysokim statusie społecznym (SES > 12). Powyższa zależność występowała u mężczyzn i kobiet analizowanych łącznie w przedziale wiekowym 30-39 lat $(\mathrm{p}=0,02)$, w przypadku kobiet różnicę wskaźnika SCORE wykazano w przedziałach wiekowych 30-39 lat $(p=0,0001)$ i 40-49 lat $(p=0,04)$, a w przypadku mężczyzn w zakresie wieku 70-74 lat $(p=0,046)$. Analiza występowania wysokiego ryzyka CVD w grupach socjoekonomicznych wykazała ujemną zależność między częstością występowania wysokiego ryzyka a wskaźnikiem SES. Wraz ze wzrostem SES malał istotnie odsetek osób z wysokim ryzykiem CVD w całej grupie mężczyzn i kobiet analizowanych łącznie oraz w przedziale wiekowym 30-39 lat $(p=0,01)$. Podobną zależność zaobserwowano w podgrupie kobiet w całym zakresie wieku i przedziale wiekowym 30-39 lat $(p=0,01)$. Wykazano związek między SES a wysokim ryzykiem CVD we wszystkich badanych grupach w przedziale wiekowym 30-39 lat (u mężczyzn i kobiet analizowanych łącznie iloraz szans wynosił 0,57 [95\% Cl 0,39-0,85; p = 0,005], u mężczyzn - 0,6 [95\% Cl 0,37-0,99; $p=0,045]$, u kobiet - 0,4 [95\% Cl 0,16-0,99; p=0,01]).

Wnioski: 1. Wykazano zależność między statusem socjoekonomicznym a podwyższonym ryzykiem CVD. 2. Niższy status socjoekonomiczny wiąże się ze zwiększonym ryzykiem CVD. Zależność ta jest silniej wyrażona u kobiet, zwłaszcza w grupie wiekowej 30-39 lat.

Słowa kluczowe: pozycja socjoekonomiczna, ryzyko wystąpienia chorób układu sercowo-naczyniowego

Kardiol Pol 2016; 74, 2: 179-184

\section{Adres do korespondencji:}

dr n. med. Ewa Podolecka, III Oddział Kardiologii, Górnośląski Ośrodek Kardiologii, Śląski Uniwersytet Medyczny, ul. Ziołowa 45/47, 40-635 Katowice, 